\title{
PENERAPAN TEKNIK 5R UNTUK MENINGKATKAN \\ KETERAMPILAN MENYIMAK MAHASISWA PRODI PGSD FKIP UST
}

\author{
Biya Ebi Praheto dan Octavian Muning Sayekti \\ Universitas Sarjanawiyata Tamansiswa \\ biya.ebi@ustjogja.ac.id
}

\begin{abstract}
This research aims to describe the improvement of listening skills through the application of $5 R$ techniques on the students of Primary School Teacher Education Program. This research is a classroom action research consisting of four stages: planning, action, observation, and reflection. This research was conducted in Primary School Teacher Education Program of Sarjanawiyata Tamansiswa University. The subject of this research is the 2nd semester students who take the Indonesian Language Skill Speech course of the academic year 2017/2018. Data collection techniques consist of observation, questionnaires, interviews, document review, and tests. Furthermore, for examination of the validity of the data used triangulation and review key information. Data analysis techniques use comparative description techniques to compare results between cycles. The result of this research is showing students who are not complete in pre cycle as many as 30 students or equal to $65,22 \%$, cycle I 41,31\% or 19 student and at cycle II 10,87\% or 5 student. On the other hand, there is an increase in learning completeness in the pre cycle of $34.78 \%$ or 16 students, increased to $58.69 \%$ or 27 students in the first cycle and $89.13 \%$ or 41 students in cycle II. While the average value in the pre cycle only reached an average of 64.13 and increased to 73.67 in cycle I and became 83 in cycle II.
\end{abstract}

Keywords: 5R technique, primary school teacher education program, listening skills

\begin{abstract}
Abstrak: Penelitian ini bertujuan untuk mengetahui peningkatan keterampilan menyimak melalui penerapan teknik 5R pada mahasiswa Program Studi Pendidikan Guru Sekolah Dasar Universitas Sarjanawiyata Tamansiswa. Penelitian ini merupakan penelitian tindakan kelas (PTK) yang terdiri atas empat tahap yaitu: perencanaan, tindakan, pengamatan, dan refleksi.Penelitian ini dilakukan di Prodi PGSD FKIP UST Yogyakarta. Subjek penelitian tindakan ini adalah mahasiswa semester 2 yang menempuh mata kuliah KBIL di Prodi PGSD FKIP UST tahun ajaran 2017/2018. Teknik pengumpulan data terdiri dari observasi, angket, wawancara atau diskusi, kajian dokumen, dan tes. Selanjutnya, untuk pemeriksaan validitas data digunakan triangulasi dan review informasi kunci. Teknik analisis data yang digunakan dalam penelitian ini adalah teknik deskripsi komparatif untuk membandingkan hasil antar siklus. Hasil dari penelitian ini yaitu menunjukkan mahasiswa yang tidak tuntas pada prasiklus sebanyak 30 mahasiswa atau sebesar $65,22 \%$, siklus I $41,31 \%$ atau 19 mahasiswa dan pada siklus II $10,87 \%$ atau 5 mahasiswa. Di sisi lain, terjadi peningkatan ketuntasan belajar yaitu pada prasiklus $34,78 \%$ atau 16 mahasiswa, meningkat menjadi 58,69\% atau 27 mahasiswa pada siklus I dan 89,13\% atau 41 mahasiswa pada siklus II. Sedangkan nilai rata-rata pada prasiklus hanya mencapai rata-rata 64,13 dan mengalami peningkatan menjadi 73,67 pada siklus I serta menjadi
\end{abstract}


83 pada siklus II.

Kata kunci: Teknik 5R, Prodi PGSD, Keterampilan Menyimak

\section{Pendahuluan}

Bahasa memiliki peran penting dalam kehidupan manusia sebagai makhluk sosial. Hal tersebut dikarenakan bahasa merupakan alat komunikasi yang paling utama. Yuliati (2017: 41) menyebutkaan bahwa Komunikasi sangat diperlukan dalam bersosialisasi di masyarakat. Komunikasi antar personal dapat dilakukan secara lisan, isyarat maupun tulisan. Untuk dapat berkomunikasi dengan baik diperlukan penguasaan bahasa yang baik pula. Selain itu, sebagai alat komunikasi, bahasa mampu mencerminkan pola pemikiran penggunanya. Semakin terampil seseorang dalam berkomunikasi, maka akan semakin jelas dan sistematis pula jalan pikirannya. Namun, keterampilan berbahasa tidaklah secara mudah diperoleh. Tentunya keterampilan berbahasa ini akan kitadapatkan dengan caraberlatih. Melatih keterampilan berbahasa berarti melatih pula keterampilan berpikir (Tarigan, 2008: 1).

Keterampilan berbahasa terdiri dari empat aspek, yaitu menyimak, berbicara, membaca, dan menulis. Keterampilan menyimak dan membaca merupakan keterampilan non produktif, sedangkan dua keterampilan lain yaitu berbicara dan menulis merupakan keterampilanproduktif. Dalam keterampilan produktif ini, kita dituntut untuk menghasilkan sesuatu secara aktif. Selain itu, menulis merupakan keterampilan yang paling tinggi tatarannya.

Berkaitan dengan keterampilan menyimak merupakan keterampilan yang dimiliki sejaklahir. Oduolowu dan Oluwakemi (2014: 100) mengungkapkan bahwalistening is the first language skill that children develop and it is the most dominant communication skill in the classroom and everyday life yaitu mendengarkan adalah keterampilan bahasa pertama yang dikembangkan anak dan merupakan keterampilan komunikasi yang paling dominan di kelas dan kehidupan sehari-hari. Keterampilan menyimak seorang anak merupakan bawaan. Hal ini dikarenakan seorang anak sejak di dalam kandungan sudah dianugerahi Langguage Acquisition Device (LAD). LAD merupakan alat berbahasa yang ada di dalam otak manusia. Bahkan dengan adanya LAD tersebut, seorang bayi sudah dapat menyimak dan membedakan suara orang-orang di sekitar mereka seperti suara ayah dan ibunya, serta lain sebagainya. Walaupunketerampilanmenyimakmerupakan keterampilan bawaan manusia sejak lahir, namun tidak menutup kemungkinan manusia juga harus mempelajari keterampilan menyimak tersebut. Hermawan (2011: 130) menyebutkan bahwa keterampilan mendengar atau menyimak adalah kemampuan seseorang dalam mencerna atau memahami kata atau kalimat yang diajarkan oleh mitra bicara atau media tertentu. Di bangku sekolah, anak diajari keterampilan berbahasa yakni menyimak, berbicara, membaca, dan menulis. Meskipun keterampilan menyimak merupakan keterampilan yang paling mudah, namun jika tidak diasah, keterampilan ini akan sulit dikuasai. Mengingat dalam menyimak dibutuhkan berbagai teknik.

Pembelajaran menyimak juga tidak hanya dipelajari di bangku sekolah, di beberapa program studi, keterampilan menyimak juga dimasukkan ke dalam kurikulum perkuliahan, seperti di jurusan pendidikan bahasa baik asing maupun bahasa Indonesia bahkan di jurusan pendidikan guru sekolah dasar. Seorang calon guru sekolah dasar juga harus memiliki bekal dan kemampuan untuk menyimak. Hal ini dikarenakan, ketika mereka nantinya menjadi seorang guru SD, mereka akan bisa melakukan pembelajaran menyimak kepada peserta didik. Sebelum mereka mampu mengajarkan keterampilan menyimak di sekolah, tentunya mereka juga harus dibekali teori dan seluk beluk 
tentang keterampilan menyimak. Selain itu, pembelajaran menyimak juga bermanfaat bagi calon guru untuk memperoleh informasi dan berbagai pengetahuan. Hal tersebut senada dengan Iskandarwassid (2008: 5960) yang menyebutkan tujuan menyimak beraneka ragam antara lain: 1) Menyimak untuk belajar, yaitu menyimak dengan tujuan utama agar dapat memperoleh pengetahuan dari bahan ujaran sang pembicara. 2) Menyimak untuk memperoleh keindahan audial, yaitu menyimak dengan penekanan pada penikmatan terhadap sesuatu dari materi yang diujarkan atau yang diperdengarkan. 3) Menyimak untuk mengevaluasi, yaitu menyimak dengan maksud agar dapat menilai apa-apa yang disimak. 4) Menyimak untuk mengapresiasi simakan, yaitu menyimak dengan maksud agar dapat menikmati serta menghargai apa-apa yang disimak. 5) Menyimak untuk mengkomunikasikan ide-idenya sendiri, yaitu menyimak dengan maksud agar dapat mengkomunikasikan ide-ide, gagasan-gagasan, maupun perasaanperasaannya kepada orang lain dengan lancar dan tepat. 6) Menyimak untuk membedakan bunyi-bunyi, yaitu menyimak dengan maksud dan tujuan agar dapat membedakan bunyi-bunyi dengan tepat mana bunyi yang membedakan arti dan mana bunyi yang tidak membedakan arti. 7) Menyimak untuk memecahkan masalah secara secara kreatif dan analisis. Dan yang terakhir 8) Menyimak untuk meyakinkan, yaitu menyimak untuk meyakinkan dirinya terhadap suatu masalah atau pendapat yang selama ini diragukan.

Mahasiswa pada jurusan Pendidikan Guru Sekolah Dasar, wajib menempuh mata kuliah Keterampilan Berbahasa Indonesia Lisan (KBIL). Di dalam mata kuliah KBIL ini, mahasiswa akan mempelajari keterampilan menyimak dan berbicara. Selain teori tentang menyimak dan berbicara, mereka juga harus menempuh praktik menyimak dan berbicara. Namun permasalahan yang ada di lapangan adalah mahasiswa masih kesulitan dalam praktik menyimak. Hal ini didapat dari hasil observasi pada hari Senin,
13 Maret 2017 kettika mata kuliah KBIL di jurusan PGSD UST. Hasil observasi tersebut memperlihatkan bahwa mahasiswa cenderung hanya merekam apa yang mereka simak dan tidak sampai menganalisis bahkan mengevaluasi bahan simakannya tersebut. Padahal yang dikatakan menyimak untuk level mahasiswa adalah kegiatan memahami, menganalisis, mengevaluasi, dan menanggapi apa yang disimaknya tersebut.

Kemampuan mahasiswa dalam hal menganalisis, mengevaluasi dan menanggapi masih sangat rendah. Mereka hanya mampu melakukan kegiatan rekam. Hal ini perlu diatasi dengan menerapkan teknik menyimak. Teknik dalam menyimak bertujuan untuk membantu penyimak dalam memahami, menganalisis, mengevaluasi, dan menanggapi bahan simakan. Teknik yang dirasa tepat untuk mengatasi permasalahan rendahnya keterampilan meyimak mahasiswa PGSD UST semester 2 tersebut yaitu teknik 5R.

Teknik 5R sudah lama diterapkan di Universitas Cornell. Universitas Cornell menerapkan suatu sistem yang dapat membantu meningkatkan pemahaman seseorang akan suatu hal, khususnya dalam proses belajar mengajar/ pembelajaran. Sistem tersebut dikenal dengan nama sistem 5R, yaiturecord (rekam), reduce (ringkas), recite (daras), reflect (renung), danreview (periksa) (Rahayu \& Musfiroh : 2004). Teknik 5R merupakan salah satu teknik yang dapat mengatasi permasalahan di atas. Teknik ini akan membantu mahasiswa dalam merekam apa yang mereka simak selanjutnya mereka juga akan dibantu dalam membuat analisis dan evaluasi dari bahan simakannya tersebut.

Penelitian berkaitan keterampilan menyimak sudah banyak dilakukan, beberapa diantaranya sebagai berikut. Pertama penelitian yang dilakukan oleh Hsu (2013: 403) dengan judulEffects of Video Caption Modes on English Listening Comprehension and Vocabulary Acquisition Using Handheld Devices. Hsu Menyatakan bahwa listening is an important capability of social interactions, and it has been found that people receive new 
messages more efficiently via listening than reading. Seain itu, penelitian yang dilakukan oleh Bozorgian dan Pillay (2013: 105) dengan judul Enhancing Foreign Language Learning through Listening Strategies Delivered in L1: An Experimental Study. Bozorgian dan Pillay menyatakan bahwa Listening used in language teaching refers to a complex process that allows us to understand spoken languageyaitu menyimak digunakan dalam pembelajaran bahasa yang mengacu pada proses yang kompleks yang memungkinkan untuk dapat memahami bahasa secara lisan.

Berdasarkan pemaparan di atas, peneliti tertarik untuk melakukan penelitian tindakan kelas dengan judul Penerapan Teknik 5R untuk Meningkatkan Keterampilan Menyimak Mahasiswa Prodi PGSD FKIP UST.

\section{Metode Penelitian}

Penelitian ini merupakan penelitian tindakan kelas (PTK) yang terdiri atas empat tahap yaitu: Perencanaan (planning), tindakan (action), pengamatan (observation), dan reflection. Penelitian tindakan adalah suatu analisis, yang diawali dari upaya menemukan fakta melalui pengamatan, merencanakan, melakukan tindakan, kemudian menemukan dan mengevaluasi temuan. Apabila temuan belum meyakinkan maka dilakukan daurulang sebagaimana semula (Wulandari \& Rahmi, 2012: 147). Dalam penelitian tindakan kelas ini dilakukan melalui dua siklus. Penelitian Tindakan Kelas ini dilakukan di Program Studi Pendidikan Guru Sekolah Dasar Fakultas Keguruan dan Ilmu Pendidikan Universitas Sarjanawiyata Tamansiswa Yogyakarta. Pemilihan tempat tersebut didasarkan pada pertimbangan (a) kondisi mahasiswa yang kesulitan dalam pembelajaran menyimak, (b) selama ini dosen belum menerapkan teknik 5R dalam pembelajarannya.Subjek penelitian tindakan ini adalah mahasiswa semester 2 yang menempuh mata kuliah Keterampilan Berbahasa Indonesia Lisan (KBIL) di Prodi PGSD FKIP UST tahun ajaran 2017/2018. Dalam hal ini dipilih kelas 2G sebagai objek penelitian dikarenakan nilai kelas $2 \mathrm{G}$ paling rendah dibandingkan dengan kelas lainnya.

Teknik yang digunakan untuk mengumpulkan data meliputi pengamatan atau observasi, angket, wawancara atau diskusi, kajian dokumen, dan tes. Teknik analisis data yang digunakan dalam penelitian ini adalah teknik deskripsi komparatif. Teknik ini digunakan untuk membandingkan hasil antar siklus. Peneliti membandingkan hasil sebelum penelitian dengan hasil pada akhir setiap siklus.

\section{Hasil Penelitian dan Pembahasan}

\section{A. Hasil Keterampilan Menyimak melalui Teknik 5R}

Tabel 1 Perbandingan Hasil Belajar antar Siklus

\begin{tabular}{|c|c|c|c|c|c|c|c|}
\hline \multirow[b]{2}{*}{ No. } & \multirow[b]{2}{*}{$\begin{array}{c}\text { Uraian Pencapaian } \\
\text { Hasil }\end{array}$} & \multicolumn{2}{|c|}{ Prasiklus } & \multicolumn{2}{|c|}{ Sklus I } & \multicolumn{2}{|c|}{ Siklus II } \\
\hline & & $\begin{array}{c}\text { Jumlah } \\
\text { Mahasiswa }\end{array}$ & $\%$ & $\begin{array}{c}\text { Jumlah } \\
\text { Mahasiswa }\end{array}$ & $\%$ & $\begin{array}{c}\text { Jumlah } \\
\text { Mahasiswa }\end{array}$ & $\%$ \\
\hline 1. & $\begin{array}{l}\text { M a h a s i s w a } \\
\text { mendapat nilai }<75\end{array}$ & 30 & $65,22 \%$ & 19 & $41,31 \%$ & 5 & $10,87 \%$ \\
\hline 2 & $\begin{array}{l}\text { M a } \mathrm{h} \text { a } \mathrm{s} \text { i } \mathrm{s} \text { w a } \\
\text { mendapat nilai } \geq 75\end{array}$ & 16 & $34,78 \%$ & 27 & $58,69 \%$ & 41 & $89,13 \%$ \\
\hline 3. & Rerata & \multicolumn{2}{|c|}{64,13} & \multicolumn{2}{|c|}{73,67} & \multicolumn{2}{|c|}{83} \\
\hline 4. & Ketuntasan Klasikal & \multicolumn{2}{|c|}{$34,78 \%$} & \multicolumn{2}{|c|}{$58,69 \%$} & \multicolumn{2}{|c|}{$89,13 \%$} \\
\hline
\end{tabular}

Penerapan teknik yang inovatif dalam pembelajaran memiliki dampak positif terhadap hasil belajar. Penerapan teknik yang tepat pembelajaran menarik dan hasil belajar sebagaimana teknik 5R yang diterapkan mahasiswa meningkat. Sebagaimana dalam pembelajaran menyimak menjadikan penelitian yang dilakukan Nurhidayah 
(2015) juga menunjukkan hasil yang sama yaitu dalam penelitiannya tersebut dapat disimpulkan bahwa penerapan teknik pencatatan 5R terbukti dapat meningkatkan keterampilan menyimak apresiatif dan kreatif terhadap film.
Secara terperinci berikut ini ditunjukkan peningkatan hasil belajar siswa tiap siklus dari penelitian ini.

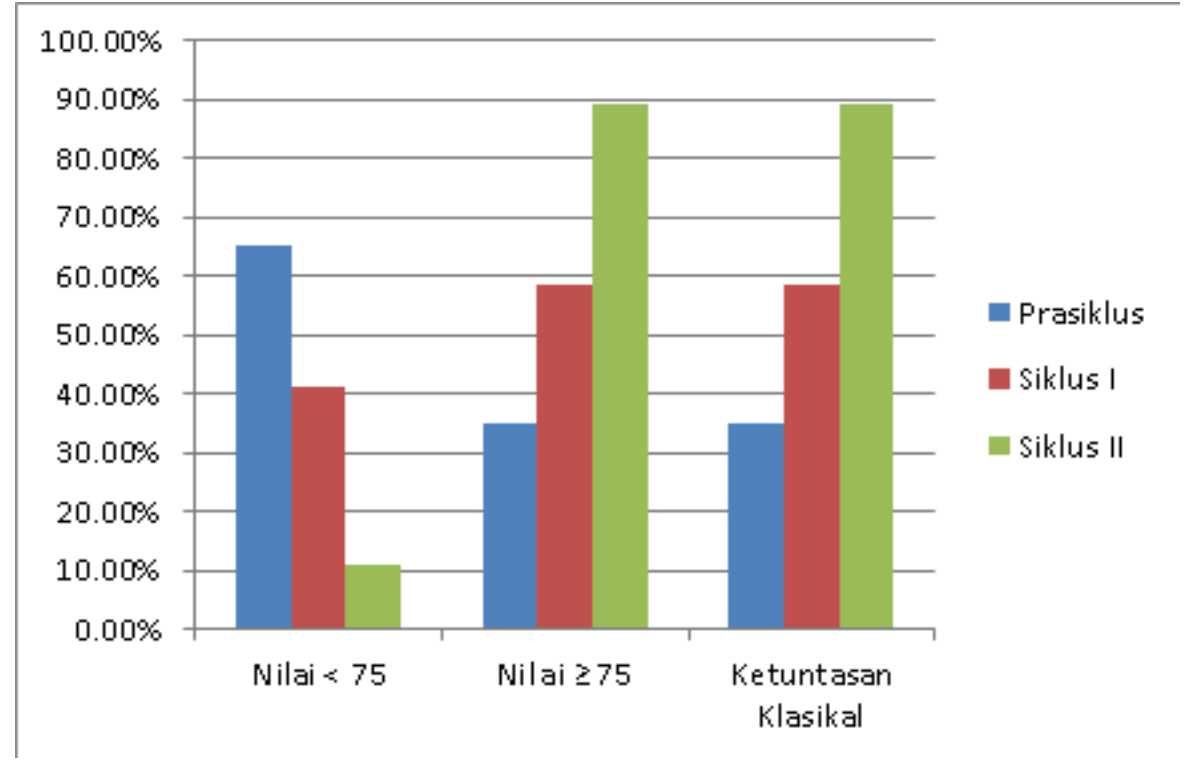

Diagram 1. Perbandingan antar siklus

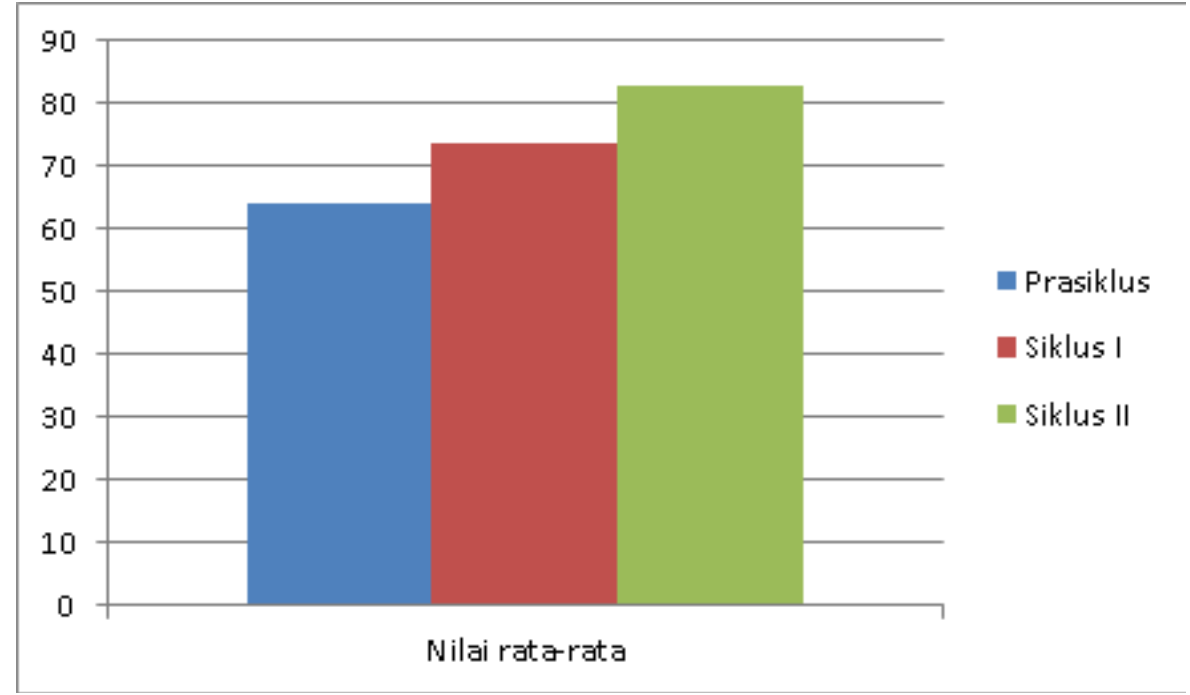

Diagram 2. Perbandingan nilai rata-rata antar siklus

Berdasarkan tabel dan diagram di atas dapat diketahui bahwa terjadi peningatan yang cukup signifikan terhadap hasil belajar menyimak mahasiswa kelas 2G. Data tersebut menunjukkan mahasiswa yang tidak tuntas pada prasiklus sebanyak 30 mahasiswa atau sebesar $65,22 \%$ dari 46 mahasiswa. Mahasiswa yang tidak tintas turun pada sikus I dan siklus II. Pada siklus satu mahasiswa tdak tuntas turun menjadi 41,31\% atau 19 mahasiswa sedangkan pada siklus II turun kembali menjadi 10,87\% atau 5 mahasiswa. Menurunnya jumlah mahasiswa yang tidak tuntas berbanding terbalik dengan meningkatnya mahasiswa yang tuntas, meningkatnya nilai rata-rata serta 
meningkatnya ketuntasan klasikal kelas $2 \mathrm{G}$. Dapat diketahui pada prasiklus mahasiswa tuntas hanya $34,78 \%$ atau 16 mahasiswa dan mengalami peningkatan menjadi $58,69 \%$ atau 27 mahasiswa pada siklus I serta kembali mengalami peningkatan pada siklus II yaitu mencapai 89,13\% atau 41 mahasiswa dinyatakan tuntas memenuhi KKM yang ditentukan. Nilai mahasiswa tuntas tersebut sama dengan nilai ketuntasan klasikal yang dicapai selama proses prasiklus, siklus I maupun siklus II. Sedangkan nilai rata-rata juga mengalami peningkatan yaitu pada prasiklus hanya mencapai rata-rata 64,13 dan nilai tersebut masih di bawah KKM yaitu 75. Nilai rata-rata mengalami peningkatan menjadi 73,67 pada siklus I dan menjadi 83 pada siklus II. Dengan dicapainya nilai ratarata pada siklus II serta ketuntasan klasikal yang mencapai lebih dari $80 \%$ maka dapat dinyatakan bahwa penelitian berhasil dan dihentikan pada siklus II dan tidak berlanjut hingga siklus III.

\section{B. Pembahasan Hasil Keterampilan Menyimak melalui Teknik 5R}

Pembelajaran menyimak merupakan pembelajaran yang mudah akan tetapi inovasi dalam pembelajarannya masih sangat kurang sehingga diperlukan adanya inovasi pembelajaran seperti penerapan teknik 5R guna meningkatkan kemampuan menyimak peserta didik. Sebagaimana penelitian yang dilakukan oleh Renukadevi (2014: 59) yang berjudul The Role of Listening in Language Acquisition; the Challenges \& Strategies in Teaching Listeningmenyatakan bahwa keterampilan menyimak secara konsisten berkitan dengan keterampilan bahasa yang lain seperti berbicara, membaca dan menulis. Akan tetapi, penilaian keterampilan menyimak masih jauh dari yang diharapkan sehingga menjadi tantangan tersendiri untuk melakukan inovasi dan merenovasi pembelajaran keterampilan menyimak.

Pelaksanaan pembelajaran keterampilan menyimak menggunkana teknik 5R sesuai dengan materi dan karakteristik mahasiswa.
Dengan penerapan teknik 5R mahasiswa terbantu untuk memahami bahan simakan secara runtut dan terperinci serta melatih kreativitas mahasiswa dalam mengungkapkan hasil simakan dalam bentuk peta konsep. Dari hasil belajar yang diperoleh mahasiswa dari tahap prasiklus, siklus I maupun siklus II terjadi perbedaan yang cukup signifikan antara pembelajaran yang masih konvensional dengan pembelajaran yang menerapkan teknik 5R.

Pada tahap prasiklus hasil belajar siswa masih jauh di bawah kriteria yaitu hanya terdapat 16 mahasiswa atau $34,78 \%$ yang tuntas mencapai nilai KKM. Sedangkan sisanya sebanyak 30 mahasiswa atau 65,22\% tidak tuntas. Di sisi lain, nilai rata-rata mahasiswa juga masih rendah di bawah KKM yaitu hanya mencapai nilai rata-rata 64,13. Hal tersebut dikarenakan mahasiswa tidak berkonsentrasi dalam kegiatan menyimak serta kurang dapat memahami bahan simakan secara baik, runtut, dan terperinci. Hal tersebut juga dipengaruhi dari faktor dosen maupun mahasiswa. Dosen tidak menerapkan tektik yang variatif yang mampu membantu mahasiswa dalam memahami bahan simakan. Dosen hanya memutarkan rekaman serta mahasiswa diminta untuk menyimak dn diberi evaluasi. Selain itu, dari segi mahasiswa kurang termotivasi dalam pembelajaran menyimak karena dianggap sulit dan tidak dapat berkonsentrasi ketika menyimak bahan simakan yang diperdengarkan. Hal tersebut menjadi salah satu faktor penyebab rendahnya hasil belajar mahasiswa.

Setelah menganalisis permasalahan yang terjadi pada prasiklus maka diterapkan suatu teknik pembelajaran sebagai solusi untuk memperbaiki pembelajaran dan hasil belajar menyimak mahasiswa. Teknik tersebut yaitu teknik 5R yang diterapkan pada tindakan siklus I dan siklus II. Hasil dari siklus I maupun siklus II dibahas sebagai berikut.

Pada pelaksanaan siklus I telah diterapkan teknik 5R dalam kegiatan menyimak dengan langkah record (rekam), reduce (ringkas), recite (daras), reflect (renung), dan review 
(periksa). Bahan simakan pada sklus I yaitu rekaman talkshow "Mata Najwa: Belajar dari Ki Hadjar". Hasil tes atau hasil belajar menyimak mahasiswa mengalami peningkatan yang cukup signifikan setelah diterapkan teknik 5R. Hasilnya yaitu ketuntasan klasikal meningkat serta rata-rata nilai pun meningkat. Pada siklus I mahasiswa tidak tuntas turun menjadi $41,31 \%$ atau 19 mahasiswa dari tahap prasiklus. Sedangkan sisanya sebesar $58,69 \%$ atau 27 mahasiswa sudah tuntas pada siklus I. Nilai rata-rata pun ikut meningkat menjadi 73,67. Peningkatan tersebut dikarenakan dosen telah menerapkan teknik pembelajaran yang inovatif serta tepat sesuai materi dan karakteristik mahasiswa. Dengan penerapan teknik 5R proses pembelajaran menjadi lebih baik serta mahasiswa terbantu untuk memahami bahan simakan dengan baik melalui langkah tahapan yang ada pada teknik 5R. Walaupun demikin, hasil yang diperoleh belum mencapai indikator keberhasilan yang telah ditentukan yaitu nilai rata-rta klasikal masih di bawah KKM dan ketuntasan klasikal masih dibawah $80 \%$, sehingg penelitian dilanjutkan kembali pada tahap berikutnya yaitu siklus II.

Pada pelaksanaan siklus II tidak jah berbeda dengan siklus I yaitu tetap menerapkan teknik 5R dalam pembelajaran menyimak. Perbedaannya hanya pada bahan simakan. Pada siklus II bahan simakannya adalah rekaman berita dari RRI. Tahapan langkah menyimak yang dilakukan mahasiswa melalui teknik 5R masih tetap sama yaitu langkah record (rekam), reduce (ringkas), recite (daras), reflect (renung), dan review (periksa). Hasil pada siklus II mengalami peningkatan dari siklus-siklus sebelumnya. Dapat diketahui pada siklus II mahasiswa tuntas mencapai $89,13 \%$ atau 41 mahasiswa, sehingga hanya ada 5 mahasiswa atau $10,87 \%$ yang tidak tuntas. Nilai rata-rata pun meningkan menjadi 83 . Hasil yang sangat baik tersebut disebabkan oleh mahasiswa yang lebih siap dalam pelaksanaan menyimak menggunakan teknik 5R. Selain itu, dosen lebih terampil dan lebih detail dalam menyampaikan tahapan-tahapan yang harus dilalui dalam proses menyimak serta merefleksi hasil pekerjaan mahasiswa pada siklus I. Hal tersebut menjadikan mahasiswa mengetahui hal-hal yang salah dalam melaksanakan kegiatan menyimak menggunakan teknik 5R dan menjadi lebih fokus dalam kegiatan menyimak. Proses pembelajaran yang semakin baik dari segi mahasiswa maupun dosen berbanding lurus dengan hasil belajar, sehingga hasil belajar pada siklus II sudah mencapai hasil yang diharapkan yaitu sesuai dengan indikator keberhasilan penelitian. Nilai rata-rata pada siklus II telah mencapai angka 83 diatas KKM 75 dan ketuntasan klasikal telah mencapai 89,13\% diatas indikator ketuntasan klasikal yang ditentukan yaitu $80 \%$. Melihat hal tersebut maka penelitian ini dinyatakan berhasil dan berhenti pada siklus II.

\section{Simpulan}

Penerapan teknik 5R dalam pembelajaran menyimak menunjukan hasil yang cukup baik dan berbanding lurus dengan hasil belajar mahasiswa. Dapat disimpulkan bahwa terjadi peningatan yang cukup signifikan terhadap hasil belajar menyimak mahasiswa kelas $2 \mathrm{G}$. Data yang diperoleh menunjukkan mahasiswa yang tidak tuntas pada prasiklus sebanyak 30 mahasiswa atau sebesar $65,22 \%$ dari 46 mahasiswa. Mahasiswa yang tidak tintas turun pada sikus I dan siklus dua. Pada siklus satu mahasiswa tidak tuntas turun menjadi 41,31\% atau 19 mahasiswa sedangkan pada siklus 2 turun kembali menjadi $10,87 \%$ atau 5 mahasiswa. Selain itu, dapat diketahui pula pada prasiklus mahasiswa tuntas hanya $34,78 \%$ atau 16 mahasiswa dan mengalami peningkatan menjadi $58,69 \%$ atau 27 mahasiswa pada siklus I serta kembali mengalami peningkatan pada siklus II yaitu mencapai $89,13 \%$ atau 41 mahasiswa dinyatakan tuntas memenuhi KKM yang ditentukan. Nilai mahasiswa tuntas tersebut sama dengan nilai ketuntasan klasikal yang dicapai selama proses prasiklus, siklus I maupun siklus II. Sedangkan nilai rata-rata 
juga mengalami peningkatan yaitu pada 75. Nilai rata-rata mengalami peningkatan prasiklus hanya mencapai rata-rata 64,13 dan menjadi 73,67 pada siklus I dan menjadi 83 nilai tersebut masih di bawah KKM yaitu pada siklus II.

\section{Daftar Pustaka}

Bozorgian, Hossein and Pillay, Hitendra. 2013. Enhancing Foreign Language Learning through Listening Strategies Delivered in L1: An Experimental Study. International Journal of Instruction January 2013 Vol.6, No.1e-ISSN: 1308-1470 page 105-122

Hermawan, Asep. 2011. Metodologi Pembelajaran Bahasa Arab. Bandung: PT Remaja Rosdakarya

Hsu, C.-K., Hwang, G.-J., Chang, Y.-T., \& Chang, C.-K. 2013. Effects of Video Caption Modes on English Listening Comprehension and Vocabulary Acquisition Using Handheld Devices. Educational Technology\& Society, 16 (1), 403-414.

Iskandarwassid dan Dadang Sunendar. 2011. Strategi Pembelajaran Bahasa. Bandung: PT. Remaja Rosdakarya

Musfiroh, Tadkiroatun \& Rahayu, Dwi hanti. 2004. Menyimak Komprehensif dan Kritis. Yogyakarta : UNY

Nurhidayah. 2015. Peningkatan Keterampilan Menyimak Apresiatif dan Kreatif Tayangan Film melalui Teknik Pencatatan 5R (Record, Reduce, Recite, Reflect, And Review). Jurnal LITERA, Vol. 14, No. 2.

Odulowu, Esther and Oluwakemi, Akintemi Eileen. Effect of Storytelling on Listening Skills of Primary One Pupil in Ibadan North Local Government Area of Oyo State, Nigeria. International Journal of Humanities and Social Science Vol. 4, No. 9, page 100-107.

Renukadevi, D. 2014. The Role of Listening in Language Acquisition; the Challenges \& Strategies in Teaching Listening. International Journal of Education and Information Studies. ISSN 2277-3169 Volume 4, Number 1 (2014), pp. 59-63

Tarigan, Henry Guntur. 2008. Menyimak Sebagai Suatu Keterampilan Berbahasa. Bandung: Angkasa.

Wulandari, Yosi \& Rahmi, Ega Aulia. 2012. Peningkatan Kemampuan Menulis Cerpen dengan Menggunakan Tekik Parafrase Puisi Siswa Kelas X1 SMA Pertiwi 1 Padang. Varia Pendidikan, Vol. 24. No. 2, hal. 147-172.

Yuliati, Farida. 2017. Penggunaan Kartu 'Superhero' untuk Meningkatkan Kemampuan Membaca Siswa Kelas I SLB YPALB Karanganyar. Varia Pendidikan, Vol. 29, No. 1, hal. 40-49. 